\title{
レモンバーム葉のラジカル消去活性に及ぼす乾燥温度の影響
}

\author{
柚木崎千鶴子 ${ }^{\S}$, 酒井美穂, 小坂妙子*, 堂園眞澄**, \\ 窄野昌信 ${ }^{* * *}$, 福田亘博*** \\ 宮崎県食品開発センター \\ *宮崎県衛生環境研究所 \\ **宮崎県総合農業試験場薬草・地域作物センター \\ *** 国立大学法人宮崎大学農学部
}

\section{Effects of Drying Temperature on Antioxidant Activity of Lemon Balm (Melissa officinalis) Leaves}

\author{
Chizuko Yukizaki ${ }^{\S}$, Miho Sakai, Taeko Kosaka*, Masumi Dozono**, \\ Masanobu Sakono*** and Nobuhiro Fukuda ${ }^{* * *}$ \\ Miyazaki Prefectural Food R\&D Center, 16500-2 Higashikaminaka \\ Sadowara-cho, Miyazaki, Miyazaki 880-0303 \\ * Miyazaki Prefectural Institute for Public Health and Enviroment, \\ 2-3-2 Gakuenkibanadai-nishi, Miyazaki, Miyazaki 889-2155 \\ ** Miyazaki Agricultural Experiment Station, 2581-88 Higashihumoto, \\ Nojiri-cho, Nishimorokata-gun, Miyazaki 886-0212 \\ *** University of Miyazaki, 1-1 Gakuenkibanadai-nishi, Miyazaki, Miyazaki 889-2192
}

\begin{abstract}
The effect of drying temperature on the antioxidant activity of lemon balm (Melissa officinalis) leaves was investigated. Lemon balm leaves were dried with a ventilation dryer at $45^{\circ} \mathrm{C}, 55^{\circ} \mathrm{C}$ and $65^{\circ} \mathrm{C}$, followed by milling. Among the three different temperature treatments, drying at $45^{\circ} \mathrm{C}$ resulted in the highest 1,1 diphenyl-2-picrylhydrazyl (DPPH) radical scavenging activity, which is an index of antioxidant activity. The concentrations of polyphenols and rosmarinic acid were also highest in the sample treated at $45^{\circ} \mathrm{C}$, suggesting that these antioxidants play an important role in the DPPH radical scavenging activity of the dry powders. On the other hand, when considering the use of dry lemon balm leaves as herbal tea, the $45^{\circ} \mathrm{C}$-, $55^{\circ} \mathrm{C}$ and $65^{\circ} \mathrm{C}$-dry powder was extracted with hot water and DPPH radical scavenging activity was measured for each. All of the hot water extracts showed some extent of DPPH radical scavenging activity; however, the highest activity was noted in the extract from the $45^{\circ} \mathrm{C}$-dry powder. The concentrations of polyphenols and rosmarinic acid in hot water extracts were also highest in the $45^{\circ} \mathrm{C}$-treated sample. These observations suggest that $45^{\circ} \mathrm{C}$ is the best drying temperature for retaining high antioxidant activity of lemon balm leaves in herbal tea production.

(Received Dec. 4, 2007 ; Accepted Mar. 10, 2008)
\end{abstract}

Keywords : lemon balm (Melissa officinalis), antioxidant activity, polyphenol, rosmarinic acid, drying temperature キーワード : レモンバーム, ラジカル消去活性, ポリフェノール, ロスマリン酸, 乾燥温度

近年，活性酸素ラジカルによる生体成分の酸化とがんを はじめとする種々の生活習慣病との関連性が指摘されてい る.これら生活習慣病の発症予防に食品由来の抗酸化性物 質の摂取が有効であると考えられ，種々の抗酸化成分， あ

干880-0303 宮崎県宮崎市佐土原町東上那珂 16500-2

$*$ \% 889-2155 宮崎県宮崎市学園木花台西 2-3-2

** $\mathbf{7} 886-0212$ 宮崎県西諸県郡野尻町大字東麓 2581-88 （現在宮崎県中部農業改良普及センター）

*** $\boldsymbol{7} 889-2192$ 宮崎県宮崎市学園木花台西 1-1

§ 連絡先 (Corresponding author), yukizaki@iri.pref.miyazaki.jp
るいはそれらを含む食品に関する研究が多く行われてい る11. これら食品の中で, スパイスやお茶用として使用さ れる種々のハーブ類の抗酸化活性が評価され ${ }^{2)}$, 関与成分 が明らかにされてきている374).八ーブ類は日本国内でも栽 培され, 宮崎県でも県総合農業試験場薬草・地域作物セン 夕ーで普及を目指した試験栽培が行われている. 我々は, 平成 15 年に宮崎県産農産物 225 試料についてラジカル消去 活性を網羅的に解析し, ハーブ類の一種であるレモンバー ム（Melissa officinalis）葉が高いラジカル消去活性を有 
することを報告した5).

ハーブ類は，一般に香辛料やハーブティーとして乾燥物 で利用される ${ }^{6)}$ 場合が多い. 乾燥は風乾によることが多い が 5〜10 日を要し ${ }^{2)}$ 天候にも左右されるため, 機械乾燥で 1〜2 日で仕上げる加工も行われている. 八ーブ類の乾燥条 件についての規定はないが，生薬類では，日本薬局方にお いて通例 $60^{\circ} \mathrm{C}$ 以下で乾燥するよう定められている。これ までに, ハーブ類の抗酸化活性に及ぼす乾燥温度の影響に ついて検討した例はほとんど見当たらない.

そこで本研究では, 短時間で乾燥可能な熱風乾燥法を用 いて, 乾燥温度がレモンバーム葉のラジカル消去活性に及 ぼす影響を検討した。 また，ラジカル消去活性に関連性が 高いと考えられるポリフェノール含量ならびにレモンバー ムの主要なポリフェノール成分であるロスマリン酸78) 含 量を測定した。 さらに，ハーブティーとしての飲用を想定 して, 各種温度で乾燥したレモンバーム葉の乾燥粉末試料 から熱水抽出液を調製し, ラジカル消去活性を測定した.

\section{実 験 方 法}

\section{1. 材料および乾燥方法}

宮崎県総合農業試験場薬草・地域作物センターで栽培さ れたレモンバームを 2004 年 5 月 25 日に収穫した。収穫し た葉茎部を水洗後水切りして, 各種温度で乾燥した。

あらかじめ $45,55,65^{\circ} \mathrm{C}$ に設定した熱風乾燥機 3 台 (ADVANTEC FV-1000, ADVANTEC FC-612, ISUZU CSHO-21ED）にレモンバーム葉をそれぞれ $1.5 \mathrm{~kg}$ ずつ入 れ，1時間ごとに重量を測定し，一定重量になるまで乾燥 した。なお, 対照として真空凍結乾燥 (FD) 物を調製した。

\section{2. 乾燥粉末試料の調製}

各種温度で乾燥して得られた乾燥物を $0.5 \mathrm{~mm}$ スクリー ンを取り付けた超遠心粉砕機 (MRK \& RETSCH, EM-1 型）で粉砕し，乾燥粉末試料を調製した。これらの乾燥粉 末試料は, 熱水抽出液の調製や分析に供するまでー $20^{\circ} \mathrm{C}$ で 保存した。

\section{3. $80 \%$ エタノール抽出液の調製}

乾燥粉末試料の DPPH ラジカル消去活性, ポリフェ ノール含量, ロスマリン酸, プロトカテク酸およびカフェ 酸含量の測定は, すべて $80 \%$ エタノール抽出液で行った. 各種温度で乾燥した乾燥粉末試料 $0.2 \mathrm{~g}$ に $80 \%$ エ夕ノール $20 \mathrm{ml}$ を加え, 室温下スターラーでかくはんしながら 10 分 間抽出後, $0.45 \mu \mathrm{m}$ フィルターでろ過し, 万液を以下に示 す分析用の試料とした。

\section{4. 熱水抽出液の調製}

ハーブティーとしての飲用を想定し, 各種温度で乾燥し た乾燥粉末試料 $0.1 \mathrm{~g}$ に沸騰水 $50 \mathrm{~g}$ を加え, $98^{\circ} \mathrm{C}$ の恒温槽 中でスターラーかくはんしながら 10 分間抽出した. $0.45 \mu \mathrm{m}$ フィルターでろ過した後水冷し, 熱水抽出液とした。これ らの熱水抽出液は, ただちに以下に示す分析に供した。

\section{5. 分析方法 \\ (1) 試 薬}

1,1-diphenyl-2-picrylhydrazyl (DPPH), Folin-Ciocalteu 溶液, ロスマリン酸およびプロトカテク酸は和光純薬工業 社製を，2-morpholinoethanesulphonic acid (MES) は同 仁化学社製を, Trolox およびカフェ酸はAldrich 社製を, また没食子酸は関東化学社製を用いた。その他の試薬は, 市販の特級品を用いた。

（2）水分含量および明度，色度の測定

乾燥粉末試料の水分含量は, $105^{\circ} \mathrm{C}$ の常圧加熱乾燥法 で測定した。 また, 乾燥粉末の明度, 色度は, 分光側色計 （MINOLTA CM-2002）で測定し, L*a* b*表色系で表示し た.

(3) DPPH ラジカル消去活性の測定

DPPH ラジカル消去活性は沖らの方法 ${ }^{9)}$ に準じて測定し, 乾燥粉末試料の乾燥重量 $1 \mathrm{~g}$ あたりの Trolox 相当量で表 した，熱水抽出液については最終エタノール濃度が $50 \%$ になるように調製して測定し， $1 \mathrm{ml}$ あたりの Trolox 相当 量で表した。

\section{（4）ポリフェノール含量の測定}

Folin-Ciocalteu 法 $^{10)}$ を用いてポリフェノール含量を測 定し, 乾燥粉末試料の乾燥重量 $1 \mathrm{~g}$ あたりの没食子酸相当 量として表した。熱水抽出液については $1 \mathrm{ml}$ あたりの没 食子酸相当量で表した。

（5）ロスマリン酸，プロトカテク酸およびカフェ酸の定量 レモンバームに含まれる主要成分であるロスマリン酸778) と, 文献に報告があり標準品の入手が可能なプロトカテク 酸およびカフェ酸8) の含量を高速液体クロマトグラフィー （HPLC）を用いて定量した. HPLC 装置として, 検出器は MD-9109（日本分光）ポンプは PU980（日本分光）グラ ジェントユニットは HG-2080-02 (日本分光)を使用した。 カラムは Finepak SIL-5（ $\phi 4.6 \mathrm{~mm} \times 250 \mathrm{~mm}$, 日本分光） を用い, カラム温度を $40^{\circ} \mathrm{C}$ とした. 移動相は, 流速 $1.0 \mathrm{ml} /$ $\min$ とし, 溶媒 A $(0.2 \%$ ギ酸溶液 $)$ および溶媒 B $(0.2 \%$ ギ 酸を含むアセトニトリル) を用い, B 液の割合を $10 \%$ から 開始し，20 分後に $30 \% ， 30$ 分後に $50 \%$ と上昇させた後, 35 分後まで $50 \%$ に維持し，40 分後に $100 \%$ まで上昇させ るプログラムで送液した。検出波長 $280 \mathrm{~nm}$ で保持時間 6.7 分前後にプロトカテク酸, 11.4 分前後にカフェ酸, 21 分前 後にロスマリン酸を検出し, 既知濃度の標準品のピーク面 積を基に含有量を算出した.

(6) HPLC-DPPH オンライン分析 ${ }^{11)}$ による抗酸化成分 ピークの確認

ポリフェノール類の分離には前項に示した装置およびカ ラムを用い, カラム温度を $40^{\circ} \mathrm{C}$ とた。移動相は, 流速を $1.0 \mathrm{ml} / \mathrm{min}$ とし, 溶媒 A（0.2\%ギ酸溶液）および溶媒 B （ $0.2 \%$ ギ酸を含むアセトニトリル）を用い， B 液の割合を 10\% から開始し，20 分後に 45\%，30 分後に $55 \%$ 上上昇さ 


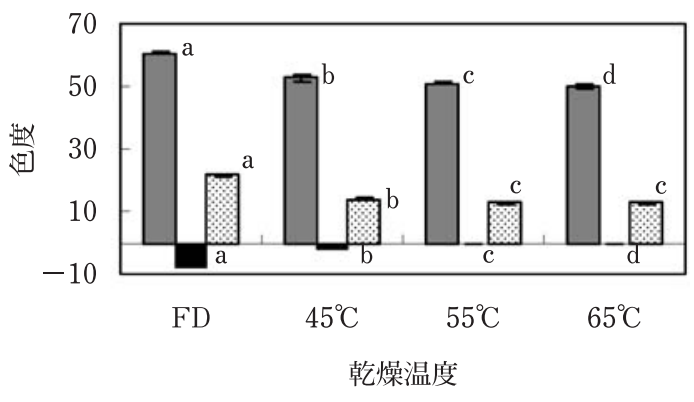

図 1 明度, 色度に及ぼすレモンバーム葉乾燥温度の影響

\section{; $\mathrm{L}^{*}, \mathbf{\square} ; \mathrm{a}^{*}$, 圆; $\mathrm{b}^{*}$}

乾燥粉末を入れたトリプルナイロン袋の表面を 10 点測定 し平均值を示すとともに標準偏差を䛊差線で示した.

各分析項目毎に a， b ， c， d : 異なる文字間に $\mathrm{p}<0.05$ で有 意差有

FD : 真空凍結乾燥

せた後，40 分後まで $55 \%$ に維持し，50 分後に 100\%まで 上昇させるプログラムで送液した。 ポリフェノール類の検 出には, $280 \mathrm{~nm}$ を用いた. UV 検出した試料液をポストカ ラムで DPPH 溶液と反応させ $517 \mathrm{~nm}$ で再検出すること により, DPPH ラジカル消去活性を示すピークを検出し た。なお，分析用サンプルには，FD 粉末試料の $80 \%$ エ夕 ノール抽出液を用いた。

(7) 統計処理法

結果は，平均值士標準偏差で表し，統計処理は Tukeykramerによる多重比較で行った。

\section{実 験 結 果}

\section{1. 乾燥時間および乾燥粉末試料の性状}

レモンバーム葉を $45,55,65^{\circ} \mathrm{C}$ で熱風乾燥した結果，乾 燥に要した時間は，それぞれ 22 時間，23 時間， 5 時間で あった。 また，調製した乾燥粉末試料の水分含量は，それ ぞれ $9.8 \%, 7.9 \%, 7.5 \%$ であった。

乾燥粉末試料の明度, 色度を測定した結果, 対照の FD 粉末試料と比較して, 熱風乾燥粉末試料の $\mathrm{L}^{*}$ 值 (明度) は 低下し， $a *$ のマイナス側 (緑色) 絶対值および b*のプラ ス側 (黄色) 絶対值は温度依存的に低下する傾向を示した (図 1)

2. DPPH ラジカル消去活性, ポリフェノール含量, ロ スマリン酸, プロトカテク酸およびカフェ酸含量

乾燥粉末試料の $80 \%$ エ夕ノール抽出液を調製し, DPPH ラジカル消去活性, ポリフェノール含量を測定しロスマリ ン酸，プロトカテク酸およびカフェ酸を定量した。その結 果, DPPH ラジカル消去活性, ポリフェノール含量および ロスマリン酸含量は，熱風乾燥粉末試料の中で， $45^{\circ} \mathrm{C}$ 乾燥 粉末試料が最も高い值を示した。乾燥重量 $1 \mathrm{~g}$ 当たりの值 は，それぞれ $435.7 \mu$ mol-Trolox 相当量/g DW, 67.5 mg没食子酸相当量/g DW および $20.8 \mathrm{mg} / \mathrm{g} \mathrm{DW}$ であった. $55^{\circ} \mathrm{C}, 65^{\circ} \mathrm{C}$ と乾燥温度が高くなるに従って $\mathrm{DPPH}$ ラジカ

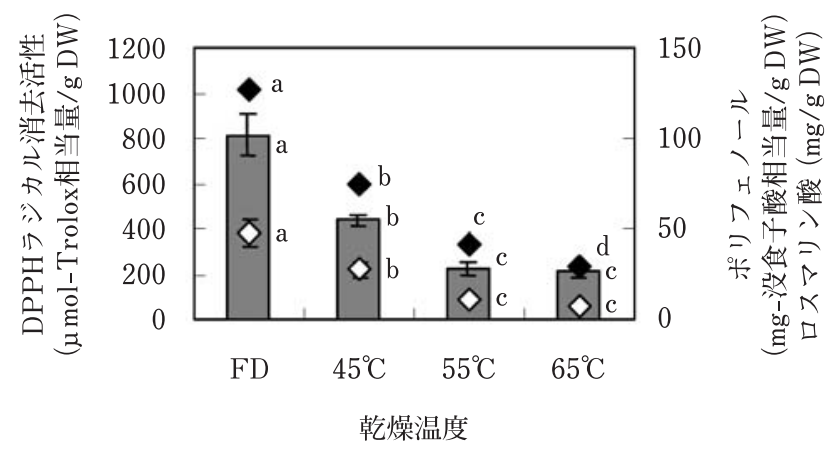

図 2 レモンバーム葉乾燥粉末 $80 \%$ エタノール抽出液の DPPH ラジカル消去活性, ポリフェノール量及びロ スマリン酸量に及ぼす乾燥温度の影響

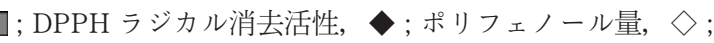
ロスマリン酸

測定は $80 \%$ エ夕ノール抽出液について 3 反復で行い平均值 を示すとともに標準偏差を䛊差線で示した。

各分析項目毎に a， b， c， d : 異なる文字間に $\mathrm{p}<0.05$ で有 意差有

$\mathrm{FD}$ : 真空凍結乾燥

ル消去活性，ポリフェノール含量およびロスマリン酸含量 の低下が見られた（図 2)。なお，プロトカテク酸およびカ フェ酸は，いずれの試料においても定量下限值未満であっ た (データ未掲載).

また，HPLC-DPPH オンライン分析により，レモンバー ム葉 FD 粉末試料 $80 \%$ エ夕ノール抽出液中の DPPH ラジ カル消去活性を示すピークを確認したところ，ロスマリン 酸以外に 8 つの゚ークが確認された（図 3 ).

3. 熱水抽出液の DPPH ラジカル消去活性, ポリフェ ノール含量およびロスマリン酸等含量

乾燥粉末から調製した熱水抽出液について 2 . と同様の 項目を測定した。その結果, 熱風乾燥粉末試料の中で $45^{\circ} \mathrm{C}$ 乾燥粉末試料の熱水抽出液が最も高い值を示した. $45^{\circ} \mathrm{C}$ 乾 燥粉末熱水抽出液 $1 \mathrm{ml}$ 当たりの值は, それぞれ $1.57 \mu \mathrm{mol}$ Trolox 相当量 $/ \mathrm{ml}, 0.23 \mathrm{mg}$ - 没食子酸相当量 $/ \mathrm{ml}, 0.06 \mathrm{mg} /$ $\mathrm{ml}$ であった。このように熱水抽出液においても, レモン バーム葉の乾燥温度が高くなるに従って, DPPH ラジカル 消去活性，ポリフェノール含量およびロスマリン酸含量が 低下することが明らかとなった（図 4).なお，プロトカテ ク酸およびカフェ酸は, 熱水抽出液においても定量下限值 未満であった (データ未掲載).

\section{考察}

乾燥温度がレモンバーム葉のラジカル消去活性に及ぼす 影響を検討した。その結果, $45^{\circ} \mathrm{C}$ 乾燥品の $\mathrm{DPPH}$ ラジカル 消去活性は, $55^{\circ} \mathrm{C}, 65^{\circ} \mathrm{C}$ 乾燥品の約 2 倍保持されているこ とが明らかとなった。ポリフェノール含量およびロスマリ ン酸含量屯 DPPH ラジカル消去活性と同様の傾向を示し ており，各測定項目間には $r>0.99$ という高い正の相関が 

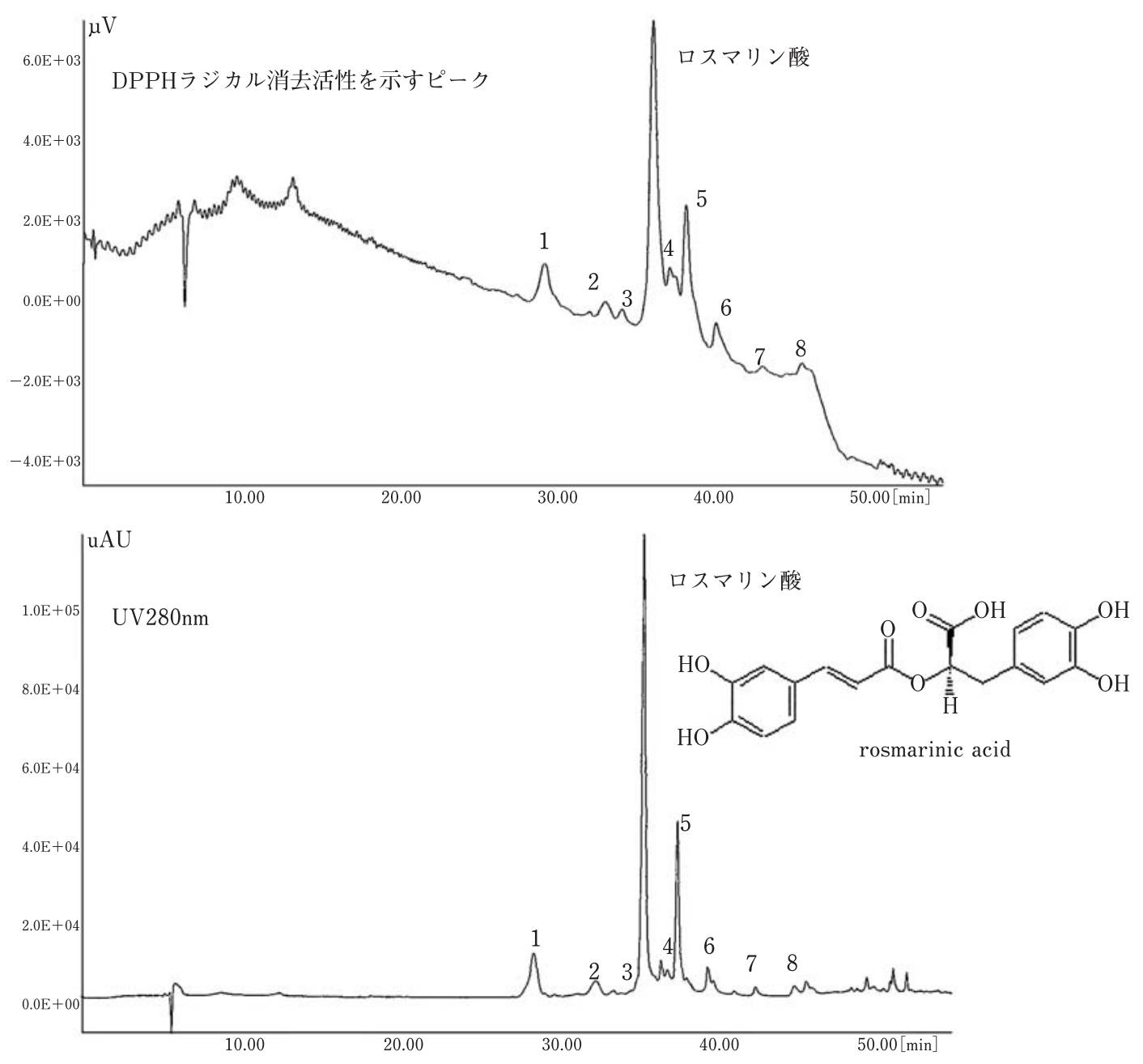

図 3 レモンバーム葉 FD 粉末 $80 \%$ エタノール抽出液の HPLC-DPPH オンライン分析による活性成分の定性

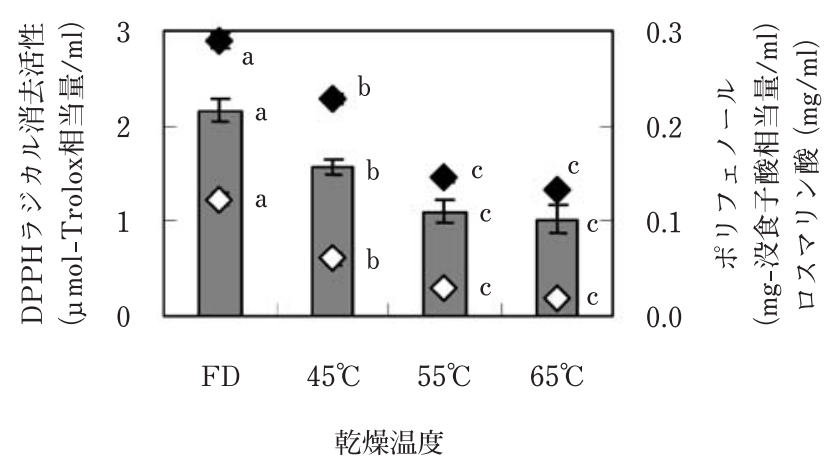

図 4 レモンバーム葉乾燥粉末熱水抽出液の DPPH ラジカ ル消去活性, ポリフェノール量及びロスマリン酸量に 及ぼす乾燥温度の影響

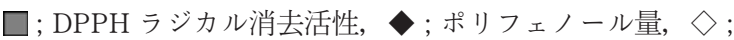
ロスマリン酸

測定は熱水抽出液について 3 反復で行い平均值を示すとと もに標準偏差を誤差線で示した。

各分析項目毎に $\mathrm{a}, \quad \mathrm{b}, \mathrm{c}$ ：異なる文字間に $\mathrm{p}<0.05$ で有意 差有
みられた。これらの結果は，レモンバーム葉エ夕ノール抽 出液の DPPH ラジカル消去活性にロスマリン酸を含むポ リフェノール類が関与していることを示唆している.

ロスマリン酸は，レモンバームを含むシソ科植物に幅広 く分布する ${ }^{12)}$ 。また，ロスマリン酸はカフェ酸の二量体で フェノール性水酸基 4 個を有する化合物であり, DPPH ラ ジカル消去活性を有することが報告されている(13)14).

本実験において, ロスマリン酸標準品の DPPH ラジカル 消去活性值 $7170 \mu$ mol-Trolox 相当量/g から, 各乾燥温度 におけるロスマリン酸の DPPH ラジカル消去活性の寄与 率を求めると, $\mathrm{FD}$ で $42.3 \%, 45^{\circ} \mathrm{C}$ 乾燥品で $45.5 \%, 55^{\circ} \mathrm{C}$ 乾燥品で $33.7 \%, 65^{\circ} \mathrm{C}$ 乾燥品で $24.5 \%$ であった。これらの 実験結果は，DPPH ラジカル消去活性を有する成分がロス マリン酸以外にも存在することを示唆している.

本研究では, HPLC-DPPH オンライン分析により, ロス マリン酸以外に DPPH ラジカル消去活性を有する 8 つ ピークを確認した. Caniova ら $^{8)}$ は，レモンバーム葉に含 まれるロスマリン酸以外のポリフェノール類として, メ夕 ノール抽出物からカフェ酸, プロトカテク酸を検出してい 
る. また, Tagashira ら ${ }^{15)}$ は同様にレモンバームの酢酸エ チル抽出物に DPPH ラジカル消去活性を見出しており, この抽出物からプロトカテク酸, カフェ酸, カフェ酸メチ ル, ロスマリン酸メチル等を検出している.今回の実験で は, DPPH ラジカル消去活性を有するピークは，ロスマリ ン酸が確認されたのみで，プロトカテク酸およびカフェ酸 は定量下限値未満であった。 Caniova $ろ^{8)}$ の報告結果との 相違は，抽出溶媒の差異あるいは原料として用いたレモン バームの産地間差異ではないかと推察される。以上の結果 から，ロスマリン酸の他に，今回同定できなかった成分が DPPH ラジカル消去活性に寄与しているあのと考えられた.

本実験では, 各種乾燥温度で処理したレモンバーム葉の ラジカル消去活性は, 乾燥温度が高いほど減少した。 また同 時に, ロスマリン酸や総ポリフェノール含量の減少が観察 された. Douglas ら ${ }^{16)}$ はエキナセア (Echinacea purpurea) を $40,55,70^{\circ} \mathrm{C}$ で乾燥し, 乾燥温度が高いほどチコリ酸の 含量が減少したことを報告している。酵素的酸化あるいは 非酵素的酸化のいずれが主因であるのかは不明であるが, チコリ酸の酸化がその原因であると示唆されている。 チコ リ酸は, ロスマリン酸と同じくカフェ酸の二量体でフェ ノール性水酸基 4 個を有する化合物であり，今回の実験で あ, 同様にロスマリン酸や他のポリフェノール類の酸化が 含量減少の原因であることが考えられる. $\mathrm{Hata}^{17)}$ は, 才 リーブ葉に含まれるユーロペイン含量の乾燥による減少 が，乾燥前のブランチング処理によって抑制できることを 報告しており，ポリフェノールオキシダーゼ活性の関与を 示唆している.さらに，ポリフェノールオキシダーゼ活性 と乾燥条件の関係に関して, Ullah ら ${ }^{18)}$ が茶葉, Lopes ら ${ }^{19)}$ がヘーゼルナッッについて検討しており，ポリフェ ノールオキシダーゼ活性には, 温度条件のみならず，水分 や水分活性が影響を及ぼすことを報告している。今回の実 験においても，ロスマリン酸やポリフェノール類の酸化 に，ポリフェノールオキシダーゼが関与している可能性が あるが，詳細の解明にはさらなる検討が必要である.

レモンバームは通常, ハーブティーとして飲用すること が多い、擛としての利用を想定して，レモンバーム葉乾 燥粉末試料の熱水抽出液を調製し, DPPH ラジカル消去活 性, ポリフェノール含量およびロスマリン酸含量を測定し た。その結果，ロスマリン酸を含むポリフェノールは熱水

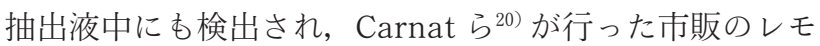
ンバーム茶葉浸出液のロスマリン酸およびポリフェノール 含量の分析結果ともよく一致した。

レモンバーム葉の乾燥温度が低いほど熱水抽出液の $\mathrm{DPPH}$ ラジカル消去活性は高く, $45^{\circ} \mathrm{C}$ 乾燥品熱水抽出液で は, $55^{\circ} \mathrm{C}, 65^{\circ} \mathrm{C}$ 乾燥品の約 1.5 倍の活性があることが示さ れ，ポリフェノール含量およびロスマリン酸含量も $\mathrm{DPPH}$ ラジカル消去活性と同様の傾向を示した（図 4).これらの ことから, 今回の実験における熱水抽出液の DPPH ラジ
カル消去活性の発現にロスマリン酸を含むポリフェノール の関与が示唆された。

さらに, 乾燥粉末試料の明度, 色度分析において, 凍結 乾燥品からの色調の保持が $45^{\circ} \mathrm{C}$ において最むよく, 特に 緑色の度合いが $55^{\circ} \mathrm{C}, 65^{\circ} \mathrm{C}$ と比較して高かった。

以上の結果から，レモンバーム葉の熱風乾燥において, 色調の保持, 機能性の保持の両面から $45^{\circ} \mathrm{C}$ 乾燥が最も適 していると考えられた。

\section{要 約}

レモンバーム葉のようなハーブ類の乾燥は，風乾による ことが多いが，5１0日を要し ${ }^{2)}$ 天候にも左右されるため， 機械乾燥屯行われている. 本研究では, レモンバーム葉の ラジカル消去活性を保持するための最適な乾燥条件を見出 すことを目的として，45，55，65 $\mathrm{C}$ で熱風乾燥試験を行 なった。各温度の乾燥粉末から $80 \%$ エ夕ノール抽出液を 調製し, DPPH ラジカル消去活性, ポリフェノール含量お よびロスマリン酸含量を測定した結果，いずれも $45^{\circ} \mathrm{C}$ 乾 燥粉末で最も高い值を示した。 また，乾燥粉末からの熱水 抽出液む, DPPH ラジカル消去活性を有しており，ロスマ リン酸を含むポリフェノールが含まれることが確認され た。乾燥温度別では $45^{\circ} \mathrm{C}$ 乾燥品が最も高いラジカル消去 活性を示すことが明らかとなった。

以上のことから，高いラジカル消去活性を保持するため には，レモンバームをハーブティーとして加工する際の乾 燥温度として $45^{\circ} \mathrm{C}$ が適切であることが示唆された。

\section{文献}

1） 大澤俊彦，酸化ストレス制御を中心とする食品機 能因子 の化学之作用機構に関する研究, 農化, 76, 804-813 (2002).

2) Capecka, E., Mareczek, A. and Leja, M., Antioxidant activity of fresh and dry herbs of some Lamiaceae species, Food Chem. 93, 223-226 (2005).

3）増田俊哉，セージ，ローズマリーに含まれる強力なジテル ペノイド抗酸化性物質の抗酸化機構, FFI JOURNAL, 209, 858-865 (2004).

4）藤江歩己, 吉田久美, 大羽和子, オレガノ葉のポリフェノー 儿化合物，食科工， 50，404-410（2003）.

5）柚木崎千鶴子，小村美穂，アショク・A・サーカー，岡部玲 二, 県内産農産物の抗酸化活性, 宮崎県工業技術センター・ 宮崎県食品開発センター研究報告，48，91-98（2003）.

6）リチャードメイビー,「ハーブ大全」, (小学館, 東京), pp 274-276 (1996).

7) Janicsak, G., Mathe, I., Miklossy, V. and Bluden, G., Comparative studies of the rosmarinic and caffeic acid contents of Lamiaceae species, Biochem. Syst. Ecol. 27, 733-738 (1999).

8) Caniova, A. and Brandsteterova, E., HPLC analysis of phenolic acids in Melissa officinalis, J Liq Chromatogr. Relat. Technol., 24, 2647-2659 (2001).

9）沖 智之, 増田真美, 吉田 収, 西場洋一, 須田郁夫, 紫サ ッマイモを原材料としたチップスのラジカル消去活性，食 科工，48，926-932 (2001).

10）津志田藤二郎，「食品機能研究法」，（光琳，東京） pp. 318- 
$322(2000)$

11) Irina, I. Koleva, Harm, A.G. Niederlander and Teris, A. van Beek, An on-line HPLC method for detection of radical scavenging compounds in complex mixtures, Anal. Chem. 72, 2323-2328 (2000).

12）中谷延二，菊崎泰枝, 食品中のポリフェノールの抗酸化活 性，農科，69，1189-1192（1995）。

13）増田俊哉, 小山保夫, 稲葉 譲, 戸井由紀子, 荒田智裕, 武 田美雄, 仲本勝男, 國永秀樹, 西里さおり, 野中 亮, 沖縄 産食薬用植物エ夕ノール抽出物の抗酸化関連活性, 食科工, 49, 652-661 (2002).

14) Chen, J.H. and Ho, C.T., Antioxidant activities of caffeic acid and its related hydroxycinnamic acid compounds, J Agric. Food Chem., 45, 2374-2378 (1997).

15) Tagashira, M. and Ohtake, Y., A new antioxidative 1,3Benzodioxole from Melissa Officinalis, Planta Med. 64, 555-558 (1998).

16) Douglas, L. Stuart and Ron, B.H. Wills, Effect of drying temperature on alkylamide and cichoric acid concentrations of Echinaceae Purpurea, J. Agric. Food Chem., 51, 1608-1610 (2003).

17) Hata, S., Effect of drying temperature on the oleuropein content of olive (Olea europea L.), Food Preservation Science, 30, 191-193 (2004).

18) Ullah, M.R. and Roy, P.C., Effect of withering on the polyphenol oxidase level in the tea leaf, Journal of Science of Food and Agriculture, 33, 492-495 (1982).

19) Lopez, A., Pique, M.T., Ferran, A., Romero, A., Boatella, J. and Garcia, J., Influence of drying conditions on the hazelnut quality : enzymatic activity, Drying Technology, 15, 979-988 (1997).

20) Carnat, A.P., Carnat, A., Fraisse, D. and Lamaison, J.L., The aromatic and polyphenolic composition of lemon balm tea (Melissa Officinalis L. subsp. Officinalis), Pharmaceutica Acta Helvetie, 72, 301-305 (1998).

(平成 19 年 12 月 4 日受付，平成 20 年 3 月 10 日受理) 